\title{
The Structural Organization of the Liver in the Chinese Fire-bellied Newt (Cynops orientalis)
}

\author{
Organización Estructural del Hígado en el Tritón de Vientre de Fuego Chino (Cynops orientalis)
}

\author{
Zhao Hui Xie; Hong Bo Zhong; Hai Jun Li \& Yu Jie Hou
}

XIE, Z. H.; ZHONG, H. B.; LI, H. J. \& HOU, Y. J. The structural organization of the liver in the Chinese fire-bellied newt (Cynops orientalis). Int. J. Morphol., 29(4):1317-1320, 2011.

SUMMARY: The morphology of Chinese fire-bellied newt liver consists of 5 lobes, with exception of a few individual differences present, which are composed by a number of hepatic lobules. Passing through the center of the lobules, a central vein radiates and is arranged in orderly row from one to several layers. The interval of the hepatic cords or masses are irregular and variable sinusoid. The hepatic sinusoidal wall consists of one layer endothelial cells or Macrophagocytus stellatus (Kupffer cells), which have protrusions and elongations. The intervals of the hepatic cells have perisinusoidal space (space of Disse). The hepatic cell is polygonal in shape with uniform, round or oval nucleus, $17.8-12.4 \mu \mathrm{m}$ in diameter, mean 14.2 $\mu \mathrm{m}$ 2-6 nucleoli, nuclear-cytoplasmic volume ratio was 0.24:1. There is a lot of pigmentation in the hepatic parenchyma.

KEY WORDS: Cynops orientalis; Liver; Histology; Morphology.

\section{INTRODUCTION}

Chinese fire-bellied newt (Cynops orientalis, David, 1873) belonging to Amphibia, Caudata, Salamandridae in classification is a local species of China. It is widely distributed at the lower reach of the Yangtze River and adjacent areas, in the hilly plains of central and Southeastern China at 30 to $1,500 \mathrm{~m}$ altitude (the provinces of Henan, Southern Anhui, Hubei, hunan) (Zhao \& Hu, 1988; Fei et al., 2006). The habitat consists of all suitable water bodies at various altitudes, mountain ponds, see pages and paddy fields in hilly areas, small brooks, flooded fields in mountain valleys, in forests and degraded areas.

Because of the growing popular studies of this species of conservation biology, evolutionary biology, developmental biology, this field has attracted more and more the attention of experts. An extensive literature search found no articles describing the Chinese fire-bellied newt liver. Several studies have been conducted on amphibian livers which are regarded as good environmental indicators (Haar \& Hightower, 1976; Barni et al., 1999; Fenoglio et al., 2005; Rohr et al., 2008) were found and will be used for comparative purpose. Our aim is to contribute to the knowledge of distinctive morphology of the Chinese firebellied newt liver and explore its adaptability to environment.

\section{MATERIAL AND METHOD}

The animals used in this experiment were 14 females and 5 males captured in their natural environment in the countryside near Guangshui, Hubei province, China (total length $40.1 \pm 2.0 \mathrm{~mm}$, weight $1.90 \pm 0.33 \mathrm{~g}$ ). The body cavity was opened and the liver was immediately fixed in $10 \%$ neutral buffered formaldehyde and Bouin's solution without acetic acid (3:1 mixture of saturated solution of picric acid in water and formalin) for $24 \mathrm{~h}$. The materials were then dehydrated in a graded series of ethanol and embedded in paraffin. Sections were cut at $7 \mu \mathrm{m}$, and processed for staining with haematoxylin and eosin and then examined in a Nikon TE2000-U microscope.

\section{RESULTS}

Anatomical observation. The liver of Chinese fire-bellied newt is located in the right anterior portion of abdominal cavity and presents dull red colour, whereas the speckled melanin as tigroid is located on the surface. The abdominal plane was swollen and flat in the dorsal plane. The surface of the liver was covered by a thin serous membrane where melanin scattered as needlepoint. Irregular small vessels 
distributed on the serous membrane in the form of a branching or treelike mark. There were five lobes of liver, the first lobe to the fifth from gastric side to right lateral body respectively (Fig. 1). The first lobe was almost $7.8 \mathrm{~mm}$ in length, $4.2 \mathrm{~mm}$ in width. The inferior border of the second lobe attached anteriorly to gastric cardia was the longest lobe almost $17.7 \mathrm{~mm}$ in length, $5.4 \mathrm{~mm}$ in width. The third lobe was the largest lobe almost $14.6 \mathrm{~mm}$ in length, $7.7 \mathrm{~mm}$ in width. The fourth lobe was as long as the first almost $8.5 \mathrm{~mm}$ in length, $3.8 \mathrm{~mm}$ in width. The fifth lobe in internal plane was almost $9.7 \mathrm{~mm}$ in length and $4.6 \mathrm{~mm}$ in width. The thickness of those lobes from the basilar part to marginal part just the same was about $0.3 \sim 3 \mathrm{~mm}$ respectively. The gallbladder showed translucent form and attached the third lobe in ventromedial part. The morphology of Chinese fire-bellied newt liver morphology presented individual differences.
Histological observation. The superficial liver of the Chinese fire-bellied newt covered with connective tissue capsule that branched and extended throughout the substance of the liver as septae (Fig. 2). It was $16.3 \pm 5.9 \mu \mathrm{m}$ in thickness. This connective tissue tree provided a scaffolding of support and the course along which afferent blood vessels and bile ducts traversed the liver. Additionally, the sheets of connective tissue divided the parenchyma of the liver into lobules. The capillary and connective fibers were obvious in the intra-mucosal. The interlobular connective tissue was underdeveloped therefore the boundary between lobules was not obvious. Passing through the center of lobules, a central vein was radiating and arranged by hepatic cord or plate. The hepatocytes around the central vein are arranged in orderly row by one to several layers. Interval of hepatic cords or masses are irregular and variable sinusoid. The wall of
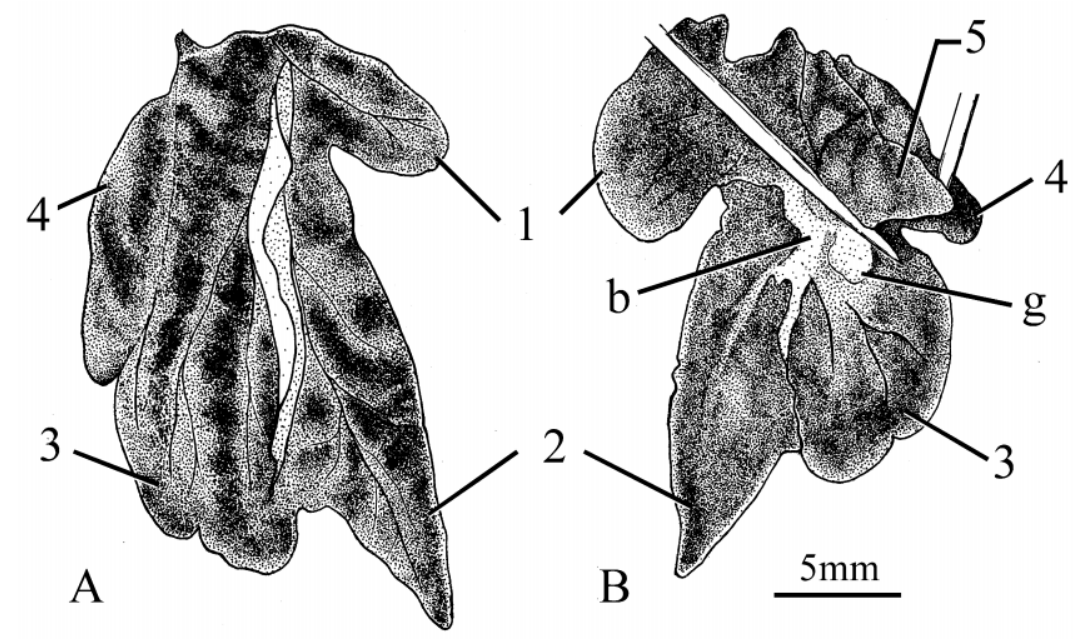

Fig. 1. The dorsal view (A) and ventral view (B) of the Chinese fire-bellied newt liver. Scale bar $=5 \mathrm{~mm}, 1-5$ are the No. 1 lobe to 5 respectively. g, gallbladder; b, bile duct.

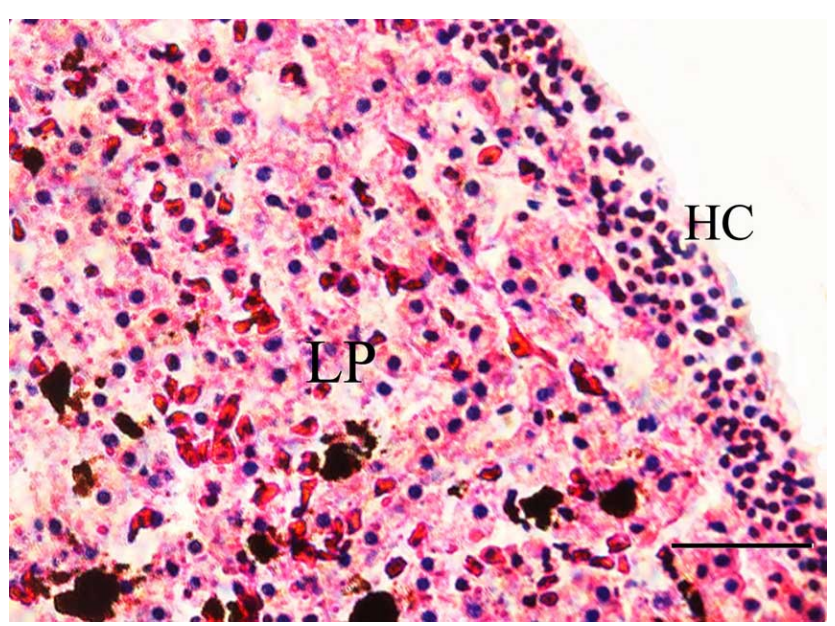

Fig. 2. Differing content of the melanin containing cells in the liver of Chinese fire-bellied newt. Stain= H \& E, Scale bar $=100 \mu \mathrm{m}$. LP, Liver parenchyma; HC, haematopoietic subcapsular tissue.

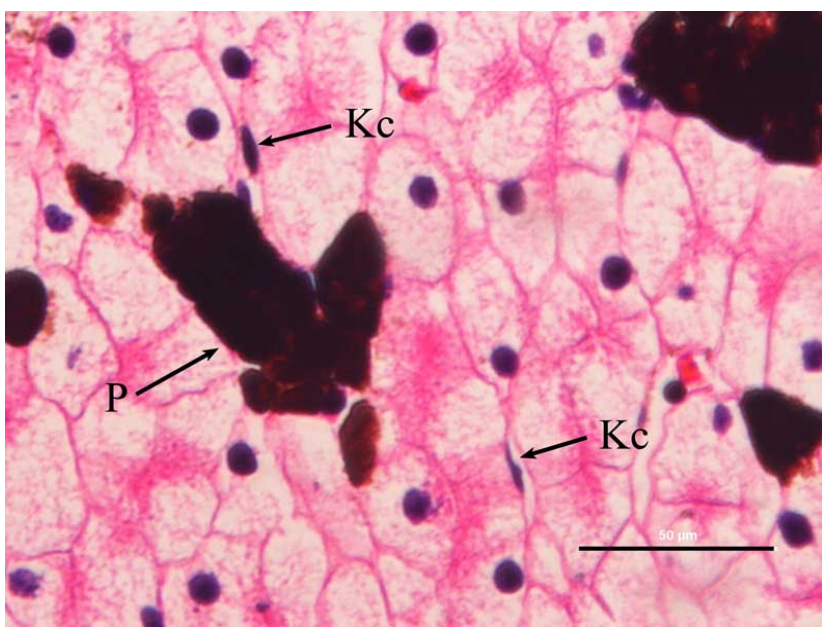

Fig. 3. Histological structure of the Chinese fire-bellied newt liver in which central vein are shown. Stain $=\mathrm{H} \& \mathrm{E}$. Scale bar $=100 \mu \mathrm{m}$. $\mathrm{P}$, pigment; $\mathrm{CV}$, central vein; $\mathrm{BD}$, bile duct. 
the hepatic sinusoid consisted of one-layer endothelial cells or macrophagocytus stellatus which have protrusions and elongations. Endothelial cells and macrophagocytus stellatus is irregular and thin flat ribbon. The interval between hepatic cells is the perisinusoidal space. The central vein was thin, 61.6-30.2 $\mu \mathrm{m}$ in diameter, mean $42 \mu \mathrm{m}$ (Fig. 3).

The hepatocytes displayed polygon (Fig. 4), 17.8$12.4 \mu \mathrm{m}$ in diameter, mean $14.2 \mu \mathrm{m}$ together with irregular unstained areas of cytoplasm. Hepatocyte nuclei were round with blue-violet color. The hepatocyte nuclei located in the central cytoplasm or a bit more on one side with 2-6 nucleoli, nuclear-cytoplasmic volume ratio was $0.24: 1$. The hepatocytes sides contacted either with sinusoids (sinusoidal face) or neighboring hepatocytes (lateral faces). Sinusoids

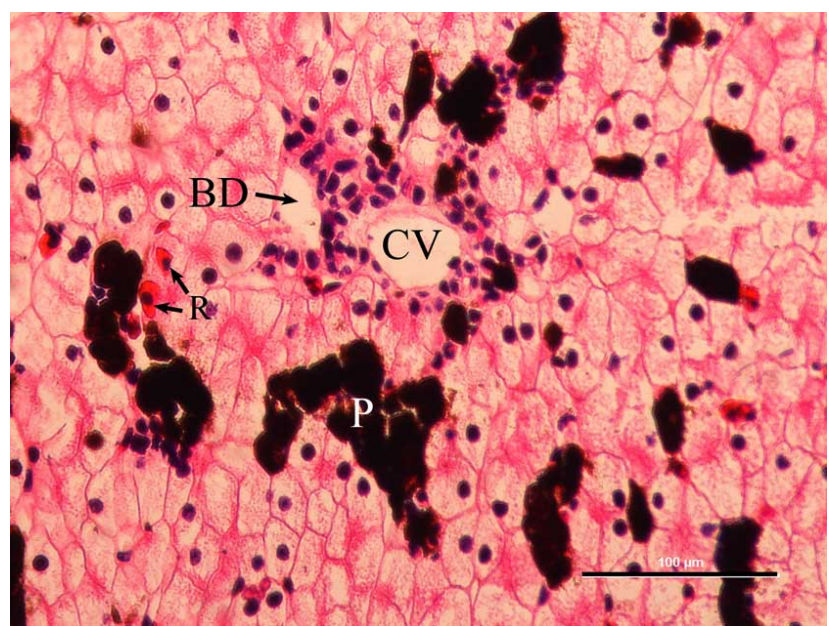

Fig. 4. The polygonal hepatocytes and Macrophagocytus stellatus from the Chinese fire-bellied newt liver in which melanin granules gathered. Stain= H \& E. Scale bar $50 \mu \mathrm{m}$. P, pigment; Kc, Kupffer cell (Macrophagocytus stellatus).

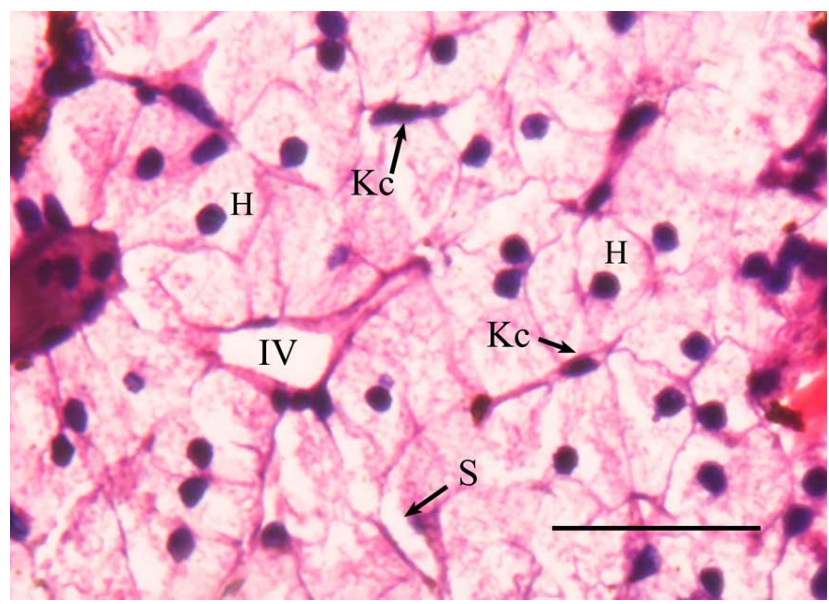

Fig. 5. The interlobular vein and sinusoid of liver in the histological section. Stain $=$ H \& E. Scale bar $50 \mu \mathrm{m}$. P, pigmentation; H, hepatocytes; Kc, Kupffer cell (Macrophagocytus stellatus ); IV, interlobular vein; S, sinusoid. were lined with endothelial cells and flanked by plates of hepatocytes and populated by numerous macrophagocytus stellatus, red blood cells can be seen among them. A large number of melanin granules gathered into clusters and are distributed unevenly (Fig. 3).

In the hepatic portal area interlobular artery, vein and bile duct were observed from superficial liver penetrated into parenchyma. The lumen of the interlobular artery the was smaller than the vein, and regular with thick wall. The interlobular bile duct was composed of simple cuboidal epithelium, $19.2 \pm 2.5 \mu \mathrm{m}$ in diameter. The epithelial cell nuclei was located in the central cytoplasm with $6.8 \pm 1.6 \mu \mathrm{m}$ in diameter (Fig. 5).

\section{DISCUSSION}

The liver is a vital organ presenting in vertebrates with a wide range of functions, including detoxification, protein synthesis, and production of biochemicals necessary for digestion. In most amphibian species, it is divided into right and left lobes (Grafflin, 1966). However, the Taiwanese frog (Hoplobatrachus regulosus) has three lobes (Chen et al., 2003). We observed the Chinese fire-bellied newt liver has five lobes, differing from previous studies that have found this species right and left lobes only (Li et al., 2005). The possibility of region polymorphism in Chinese fire-bellied newt liver presumably exists.

The hepatocytes are polyhedral, with 5 or more surfaces. The nuclei are large and round, located in lateral cytoplasm in common. The cytoplasm with irregular unstained areas corresponds to cytoplasmic glycogen and lipid stores removed during histological preparation. Owing to such variations in different nutritional conditions, it is assumed that the liver cells represent important storage of energy.

Haar \& Hightower described that fine structural characteristics of hepatocytes in newt Notophthalmus viridescens included abundant lipid and glycogen inclusions. Melanophores with developing melanosomes are situated throughout the hepatic parenchyma. Those results are similar to our observation in the Chinese fire-bellied newt. The melanins of the liver pigment cells are considered belonging to the reticulohistiocytic system (also defined as the mononuclear phagocytic system) and deriving from macrophagocytus stellatus based on their localization and phagocytic capacity (Rund et al., 1998; Barni et al.). It seems to play an important role as scavengers of cytotoxic substances such as ions and free radicals (Barni et al.; Frangioni et al., 2005). The newt Triturus carnifex holds 
melanin and hemosiderin in the macrophagocytus stellatus. Synthesis of the mixed polymer is possible through the wellknown capacity of ferrous iron to activate tyrosinase (the enzyme responsible for melanogenesis) even in the absence of DOPA (Frangioni et al., 2005). The genic expression of tyrosinase in hypoxia appears to be a physiological response aimed at prolonging survival time in anaerobiosis by lowering the metabolic level; melanin would be an inert subproduct of this function (Frangioni et al., 2000). As a consequence of protective adaptability of Chinese fire-bellied newt liver characterized by melanin aggregated in anaerobiosis environment, the molecular mechanism of melanin should be the subject of further study.

ACKNOWLEDGEMENTS. The authors gratefully acknowledge the financial support from Henan University of Urban Construction. Special thanks to Prof. Linna Shan for helpful comments. The study was made in compliance with the national laws governing the use of animals in scientific studies.

XIE, Z. H.; ZHONG, H. B.; LI, H. J. \& HOU, Y. J. Organización estructural del hígado en el tritón de vientre de fuego Chino (Cynops orientalis). Int. J. Morphol., 29(4):1317-1320, 2011.

RESUMEN: La morfología del hígado del tritón de vientre de fuego chino está constituida por 5 lóbulos, excepto unos pocos que presentan diferencias individuales, los cuales se componen de una gran cantidad de lóbulos hepáticos. Pasando por el centro de los lóbulos, se encuentra una vena central radial y los organiza en cordones o placas hepáticas. La vena central es delgada de 61,6-30,2 $\mu \mathrm{m}$ de diámetro, con una media $42 \mathrm{de} \mu \mathrm{m}$. Los hepatocitos alrededor de la vena central están organizados en filas ordenadas por una a varias capas. El intervalo de los cordones hepáticos o masas es irregular y sinusoidal variable. La pared del sinusoide hepático está formada por una capa de células endoteliales o macrófagos hepáticos (células de Kupffer) que tienen protuberancias y elongaciones. El intervalo de las células hepáticas tienen el espacio perisinusoidal (de Disse). La célula hepática es de forma poligonal con un núcleo redondo u oval uniforme de 17,8-12,4 $\mu \mathrm{m}$ de diámetro, con una media 14,2 $\mu \mathrm{m}$. 2 a 6 nucléolos, con un radio de volumen nuclear-citoplasmático de 0,24:1. Hay una gran cantidad de pigmentación en el parénquima hepático.

PALABRAS CLAVE: Cynops orientalis; Hígado; Histología; Morfología.

\section{REFERENCES}

Barni, S.; Bertone, V.; Croce, A. C.; Bottiroli, F. \& Gerzeli, G. Increase in liver pigmentation during natural hibernation in some amphibians. J. Anat., 195(Pt 1):19-25, 1999.

Chen, X. Q.; Jiang, J. P. \& Lin, W. Histology of the digestive gland in Hoplobatrachusrugulosus. J. Fujian Norm. Univ. (Nat. Sci.), 19:117-20, 2003.

Fei, L.; Hu, S.; Ye, C. \& Huang, Y. Fauna Sinica, Amphibia. Beijing, Science Press, 2006. Vol. I.

Fenoglio, C.; Boncompagni, E.; Fasola, M.; Gandini, C.; Comizzoli, S.; Milanesi, G. \& Barni, S. Effects of environmental pollution on the liver parenchymal cells and Kupffermelanomacrophagic cells of the frog Rana esculenta. Ecotoxicol. Environ. Saf., 60(3):259-68, 2005.

Frangioni, G.; Borgioli, G.; Bianchi, S. \& Pillozzi, S. Relationships between hepatic melanogenesis and respiratory conditions in the newt, Triturus carnifex. J. Exp. Zool., 287(2):120-7, 2000.

Frangioni, G.; Santoni, M.; Bianchi, S.; Franchi, M.; Fuzzi, G.; Marcaccini, S.; Varlani, C. \& Borgioli, G. Function of the hepatic melanogenesis in the newt, Triturus carnifex. J. Exp. Zool. A Comp. Exp. Biol., 303(2):123-31, 2005.

Grafflin, A. L. In vivo studies of hepatic structure and function in the salamander. Anat. Rec.,115(1):53-61,1966.
Haar, J. L. \& Hightower, J. A. A light and electron microscopic investigation of the hepatic parenchyma of the adult newt, Notophthalmus viridescens. Anat. Rec., 185(3):313-23, 1976.

Li, S. C.; Liu, X. L. \& Hao, X. Morphologic observation and anatomical study on Cynops orientalis. Chinese J. Vet. Sci. Technol., 35:60-63, 2005.

Rohr, J. R.; Schotthoefer, A. M.; Raffel T. R.; Carrick, H. J.; Halstead N.; Hoverman, J. T.; Johnson, C. M.; Johnson, L. B.; Lieske, C.; Piwoni, M. D.; Schoff, P. K. \& Beasley, V. R. Agrochemicals increase trematode infections in a declining amphibian species. Nature, 455(7217):1235-9, 2008.

Rund, C. R.; Christiansen, J. L. \& Johnson, J. C. In vitro culture of melanomacrophages from the spleen and liver of turtles: comments on melanomacrophage morphology. Pigment Cell Res., 11(2):114-9, 1998.

Zhao, E. \& Hu, Q. Studies on Chinese Tailed Amphibians. Oxford, Society for the Study of Amphibians and Reptiles, 1988. pp.1-48.

\section{Correspondence to \\ Zhao Hui Xie \\ Department of Bioengineering \\ Henan University of Urban Construction \\ Mingyue Road, New zone Pingdingshan \\ Henan, 467000 \\ CHINA}

Received: 16-07-2011

Email: xiezhaohui@hncj.edu.cn
Accepted: 05-09-2011 